\title{
Comparative analysis of clinical features and risk factors of severe pneumonia development in pediatric patients hospitalized with seasonal influenza or swine-origin influenza infection
}

\author{
Ling Jin ${ }^{1, B-F}$, En-Mei Liu ${ }^{2, B, C, E, F}$, Xiao-Hong Xie ${ }^{2, C, E, F}$, Ying Hu, ${ }^{1, C, F}$, Wei Liao ${ }^{1, A, C, E, F}$ \\ ${ }^{1}$ Department of Pediatrics, First Affiliated Hospital (Southwest Hospital) of The Third Military Medical University, Chongqing, China \\ ${ }^{2}$ Respiratory Center of the Affiliated Children's Hospital of Chongqing Medical University, China \\ A - research concept and design; $\mathrm{B}$ - collection and/or assembly of data; $\mathrm{C}$ - data analysis and interpretation; \\ $\mathrm{D}$ - writing the article; $\mathrm{E}$ - critical revision of the article; $\mathrm{F}$ - final approval of the article
}

\section{Address for correspondence}

Wei Liao

E-mail:540696970@qq.com

\section{Funding sources}

This study was granted by China Special Grant for the Prevention and Control of Infection Diseases (grant No. 2009ZX10004-204), 2016 Military Medical Science and Technology Innovation Program (SWH2016LCYB-15).

\section{Conflict of interest}

None declared

Received on September 21, 2017 Reviewed on November 20, 2017 Accepted on April 30, 2020

Published online on August 13, 2020

\section{Cite as}

Jin L, Liu EM, Xie XH, Hu Y, Liao W. Comparative analysis of clinical features and risk factors of severe pneumonia development in pediatric patients hospitalized with seasona influenza or swine-origin influenza infection. Adv Clin Exp Med. 2020;29(8):971-977. doi:10.17219/acem/121520

DOI

10.17219/acem/121520

\section{Copyright}

Copyright by Author(s)

This is an article distributed under the terms of the

Creative Commons Attribution 3.0 Unported (CC BY 3.0)

(https://creativecommons.org/licenses/by/3.0/)

\begin{abstract}
Background. The influenza A virus is the most important human pathogen affecting respiratory tract in children and has been prevalent for more than a century.

Objectives. To describe epidemiological and clinical features in hospitalized children with acute respiratory infection caused by a novel swine-origin influenza virus (S-OIV) and seasonal influenza virus A (IVA).

Material and methods. A total of 1,074 nasopharyngeal aspirate (NPA) samples were collected from children hospitalized with acute respiratory tract infections. The RNAs of S-OIV and seasonal IVA in the samples were examined using real-time polymerase chain reaction (RT-PCR).

Results. The presence of IVA was detected in 105 samples (9.8\%), including S-OIV in 15 samples (1.4\%) and seasonal IVA in the remaining samples (8.4\%). The incidence of both viral infections was lower in autumn and winter. The rates of severe pneumonia in patients with S-OIV and seasonal IVA were $6.7 \%$ and $15.6 \%$, respectively. In total, 14 out of 90 seasonal IVA-positive cases were categorized as severe pneumonia and 1 out of $15 \mathrm{~S}$-OIV-positive cases as severe bronchiolitis. Five samples were found to have single S-OIV infection among 15 S-0IV-positive cases, while other respiratory viruses were detected in the other 9 samples. Twenty-one samples were found to be single seasonal-IVA-positive among the 90 seasonal-IVA-positive cases. Underlying heart conditions (odds ratio $(O R)=13.60)$, wheezing $(O R=6.82$ ) and co-infection with adenovirus $(O R=6.21)$ were risk factors for developing severe pneumonia in seasonal IVA patients.

Conclusions. Children younger than 2 years appeared to be susceptible to both kinds of viral infection. Diagnoses of non-severe respiratory tract infection were mainly made for patients with S-OIV and IVA infection. Underlying heart conditions, wheezing and co-infection with adenovirus increase the risk of developing severe pneumonia in seasonal IVA patients.
\end{abstract}

Key words: children, swine-origin influenza virus, seasonal influenza virus A, acute respiratory tract infection 


\section{Introduction}

Influenza A virus (IVA) is the most important pathogen of respiratory tract infection in children and has been prevalent for more than a century. The flu has caused epidemics every year and erupts into a global pandemic at intervals of about 40 years. ${ }^{1}$ The most common symptoms of flu pediatric patients include fever, cough and sputum. ${ }^{2} \mathrm{Be}-$ cause of the antigenic drift or antigenic shift of the hemagglutinin and neuraminidase glycoproteins of the influenza viruses, the clinical features vary from year to year. Such is the case with the swine-origin influenza A (H1N1) virus (S-OIV). ${ }^{3}$

In April 2009, the first infection of S-OIV in humans was reported in Mexico, and the virus has rapidly spread across the world, affecting mainly young adults and children. The S-OIV probably resulted from the reassortment of recent North American H3N2 and H1N2 swine viruses (that is, avian/human/swine 'triple' reassortant viruses) with Eurasian avian-like swine viruses. ${ }^{4}$ The main presentation of S-OIV was fever, cough, runny nose, nausea, poor feeding, and labored breathing in children, ${ }^{5}$ which was more obvious in gastrointestinal symptoms than seasonal influenza. Because of the risk of emerging epidemics and pandemics, influenza always attracts the attention of patients, physicians, health organizations, and the media. ${ }^{6}$ Information on the clinical course of children infected with $\mathrm{H} 1 \mathrm{~N} 1$ is still emerging. ${ }^{7,8}$

In this study, the purpose was to describe the clinical features, laboratory examination results and risk factors of severe pneumonia development in children after seasonal influenza or S-OIV infection, with the respiratory infectious pediatric patients admitted to Children's Hospital of Chongqing Medical University (China) serving as the test subjects.

\section{Material and methods}

\section{Participants and clinical methods}

The study population consisted of 1,074 children under the age of 16 years who were admitted to the Division of Respiratory Medicine at Children's Hospital of Chongqing Medical University between June 1, 2009 and May 31,2011 . During the two-year study period, out of 1,074 pediatric patients, 90 had a confirmed IVA infection and 15 had confirmed S-OIV infection. These 105 pneumonia patients with IVA or S-OIV infection were divided into a severe pneumonia group and a non-severe pneumonia group. The demographic, clinical and laboratory data extracted from medical records for the study included complete blood count, respiratory tract immune fluorescence, sputum culture for bacteria, radiological findings, and epidemiological data, using a standardized datasheet. Subjective symptoms such as headache, sore throat and myalgia were also assessed, but only in children older than 5 years. The diagnosis of pneumonia and severe pneumonia were mainly based on the guidelines from the Pediatrics Branch Respiratory Study Group of the Chinese Medical Association. ${ }^{9}$ The comparison was done between severe pneumonia patients and non-severe pneumonia patients. Clinical and laboratory data was compared between patients with seasonal influenza and those with S-OIV.

All patients or their legal guardians gave informed consent to participate in this study. The study was carried out in accordance with the Helsinki Declaration.

\section{Laboratory confirmation}

All specimens were collected using nasopharyngeal aspirates (NPAs) method. The NPAs were stored at $4^{\circ} \mathrm{C}$ for a short duration (4-6 h) in the hospital ward; then, they were transported on ice to the Lab for Pediatric Respiratory Medicine of the Children's Hospital of Chongqing, where they were divided into centrifuge tubes and stored at $-80^{\circ} \mathrm{C}$. DNA and RNA were co-extracted from 200- $\mu$ L NPA samples using QIAamp ${ }^{\circledR}$ MinElute Virus Spin Kits (Qiagen, Hilden, Germany) according to the manufacturer's instructions, and the samples were eluted in $62 \mu \mathrm{L}$ of RNase-free water. Then, cDNA was synthesized using a SuperScript ${ }^{\circledR}$ First-Strand Synthesis System for real-time polymerase chain reaction (RT-PCR; Invitrogen, Carlsbad, USA). The RT-PCR was used to detect IVA and S-OIV. Nested PCR assays - providing a higher sensitivity than non-nested PCR - detected parainfluenza viruses (PIVs), respiratory syncytial virus (RSV), human metapneumovirus (hMPV), and Netherlands human coronavirus ( $\mathrm{HCoV})$; the PCR method was used to detect Aleutian disease virus (ADV). ${ }^{9-13}$ The primers used in the experiments are listed in Table 1.

Table 1. Primers and probes for RT-PCR

\begin{tabular}{|l|c|c|}
\multicolumn{1}{|c|}{$\begin{array}{c}\text { Primers } \\
\text { and probes }\end{array}$} & Sequence $\left(5^{\prime}-3^{\prime \prime}\right)$ & $\begin{array}{c}\text { Working } \\
\text { concen- } \\
\text { tration }\end{array}$ \\
\hline IVA forward & AAAGCGAATTTCAGTGTGAT & $0.2 \mu \mathrm{M}$ \\
\hline IVA reverse & GAAGGCAATGTGAGATTT & $0.2 \mu \mathrm{M}$ \\
\hline IVA probe & GAAAGCCCGGTCCCTCTT & $0.1 \mu \mathrm{M}$ \\
\hline S-OIV forward & GCACGGTCAGCACTTATYCTRAG & $0.2 \mu \mathrm{M}$ \\
\hline S-OIV reverse & GTGRGCTGGGTTTTCATTTGGTC & $0.2 \mu \mathrm{M}$ \\
\hline S-OIV probe & CYACTGCAAGCCCA"T"ACACACAAGCAGGCA & $0.1 \mu \mathrm{M}$ \\
\hline
\end{tabular}

IVA - seasonal influenza virus A; S-OIV - swine-origin influenza virus.

\section{Statistical analysis}

Statistical analyses were performed using SPSS v. 17.0 software (SPSS Inc., Chicago, USA). Data is expressed as mean \pm standard deviation (SD), median, percentage, or frequency. The $\mathrm{X}^{2}$ test was used to compare categorical 
variables, with Fisher's correction when needed. The t-test was used for comparing continuous variables. To analyze for the risk factors of severe pneumonia, we used multivariate logistic regression. Odds ratios (ORs) and 95\% confidence intervals (95\% CIs) were calculated. A two-tailed p-value of less than 0.05 was considered statistically significant.

\section{Results}

During the two-year study period, out of 1,074 pediatric patients, 90 had confirmed IVA infections and 15 had confirmed S-OIV infections. The age of the IVA patients ranged from 1 to 135 months (median age: 9 months) while the age of the S-OIV patients ranged from 1 to 63 months (median age: 9 months). Of note, there were significantly more males than females, at a ratio of $2: 1$ and 4:1 for IVA and S-OIV infections, respectively. Most patients (76.6\% and $79.9 \%$, respectively) were younger than 2 years. Approximately $40 \%$ of both had an underlying medical condition, such as premature labor, previous respiratory infection ( $\geq 3$ ), asthma, or congenital heart disease. Meanwhile, there were no significant differences regarding demographic characteristics between the IVA and S-OIV groups ( $\mathrm{p}>0.05$; Table 2 ).

The clinical manifestations of IVA or S-OIV infection in the hospitalized pediatric patients are listed in Table 3. The results indicate that there were no significant differences in the symptoms, signs and blood parameters between the IVA and S-OIV groups ( $p>0.05$; Table 3). The most common symptoms of IVA or S-OIV patients at admission were mainly cough $(94.4 \%$ and $100.0 \%$,

Table 2. Demographic characteristics of 90 patients hospitalized with IVA and 15 patients with S-OIV

\begin{tabular}{|c|c|c|c|}
\hline Characteristic & IVA $(n=90)$ & S-OIV $(n=15)$ & $p$-value \\
\hline Sex & $\begin{array}{c}\text { male, } 60(66.7 \%) \\
\text { female, } 30(33.3 \%)\end{array}$ & $\begin{array}{l}\text { male, } 12(80 \%) \\
\text { female, } 3(20 \%)\end{array}$ & $>0.05$ \\
\hline Age groups & $\begin{array}{c}>5 \text { years, } 7(7.8 \%) \\
2-5 \text { years, } 14(15.6 \%) \\
<2 \text { years, } 79(76.6 \%)\end{array}$ & $\begin{array}{l}>5 \text { years, } 1(6.7 \%) \\
2-5 \text { years, } 2(13.4 \%) \\
<2 \text { years, } 12(79.9 \%)\end{array}$ & $>0.05$ \\
\hline Median age (range) & 9 months (1-135) & 9 months (1-63) & $>0.05$ \\
\hline $\begin{array}{l}\text { Underlying medical conditions } \\
\text { premature }(<37 \text { weeks) } \\
\text { previous respiratory infection }(\geq 3) \\
\text { asthma } \\
\text { congenital heart disease }\end{array}$ & $\begin{array}{l}34(37.8 \%) \\
8(8.9 \%) \\
13(14.4 \%) \\
10(11.1 \%) \\
7(7.8 \%)\end{array}$ & $\begin{array}{l}6(40.0 \%) \\
2(13.3 \%) \\
4(26.7 \%) \\
2(13.3 \%) \\
0(0.0 \%)\end{array}$ & $\begin{array}{l}>0.05 \\
>0.05 \\
>0.05 \\
>0.05 \\
>0.05\end{array}$ \\
\hline
\end{tabular}

IVA - seasonal influenza virus A; S-OIV - swine-origin influenza virus.

Table 3. Clinical features of 90 IVA patients and 15 S-OIV patients

\begin{tabular}{|c|c|c|c|}
\hline Clinical feature & $\begin{array}{c}\text { IVA } \\
(n=90)\end{array}$ & S-OIV $(n=15)$ & $p$-value \\
\hline \multicolumn{4}{|c|}{ Symptom } \\
\hline Cough & $85(94.4 \%)$ & 15 (100.0\%) & 0.455 \\
\hline Sputum & 63 (70.0\%) & $7(46.7 \%)$ & 0.076 \\
\hline Fever & $54(60.0 \%)$ & $10(66.7 \%)$ & 0.425 \\
\hline Wheezing & $29(32.2 \%)$ & $5(33.3 \%)$ & 0.574 \\
\hline Dyspnea & $12(13.3 \%)$ & $1(6.7 \%)$ & 0.412 \\
\hline Fatigue & $6(6.7 \%)$ & $0(0.0 \%)$ & 0.387 \\
\hline Sore throat & $1(1.1 \%)$ & $0(0.0 \%)$ & 0.857 \\
\hline Headache & $2(2.2 \%)$ & $0(0.0 \%)$ & 0.734 \\
\hline Chest pain & $1(1.1 \%)$ & $0(0.0 \%)$ & 0.857 \\
\hline Abdominal pain & $2(2.2 \%)$ & $0(0.0 \%)$ & 0.734 \\
\hline \multicolumn{4}{|c|}{ Sign } \\
\hline Moist & 64 (71.1\%) & $9(60.0 \%)$ & 0.300 \\
\hline Wheeze & $39(43.3 \%)$ & $5(33.3 \%)$ & 0.307 \\
\hline \multicolumn{4}{|c|}{ Hemanalysis } \\
\hline WBC $\left[/ \mathrm{mm}^{3}\right]$ & $9926 \pm 4170$ & $9611 \pm 5224$ & 0.915 \\
\hline CRP [mg/dL] & $8.569 \pm 27.93$ & $15.83 \pm 38.66$ & 0.483 \\
\hline
\end{tabular}

IVA - seasonal influenza virus A; S-OIV - swine-origin influenza virus; WBC - white blood cell count; CRP - C-reactive protein level. 


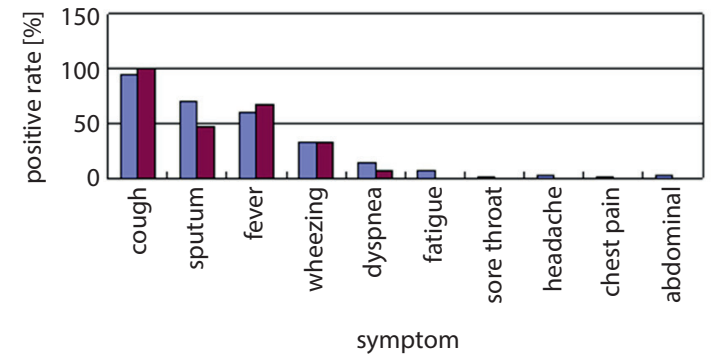

Fig. 1. The symptoms in IVA and S-OIV infection

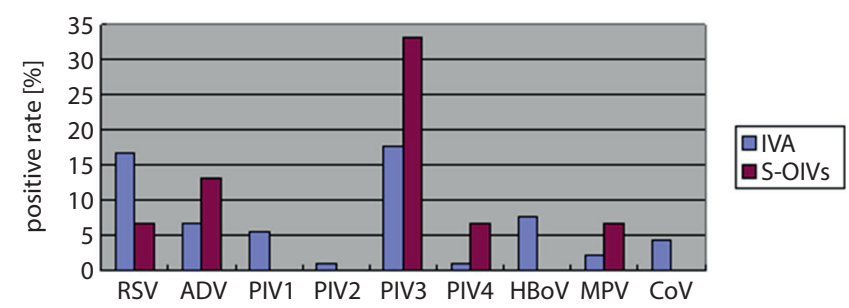

Fig. 2. Viral co-infection in IVA and S-OIV infection

respectively), fever (60.0\% and $66.7 \%$, respectively) and sputum $(70.0 \%$ and $46.7 \%$, respectively). The symptoms of fatigue, sore throat, headache, abdominal pain, and chest pain were rare in both groups of patients (Fig. 1). Physical examination at admission found moist $(71.7 \%$ and $60.0 \%$, respectively) and wheezing $(43.3 \%$ and $33.3 \%$, respectively). Detailed blood test results were collected within $24 \mathrm{~h}$ of admission. The white blood cell (WBC) count was almost normal, while the C-reactive protein (CRP) level was higher than average, especially in the S-OIV patients.

Out of the 90 IVA-positive cases, 39 (43.3\%) had co-infection with other common respiratory viruses, while $9(60.0 \%)$ S-OIV-positive cases had co-infection. The most common co-infection for both was PIVs $(25.6 \%$ and $40.0 \%$, respectively) - especially PIV3 (17.8\% and $33.3 \%$, respectively) - followed by RSV (16.7\% and 6.7\%, respectively) and ADV (6.7\% and $13.3 \%$, respectively). Co-infection with hMPV or $\mathrm{HCoV}$ was relatively rare. However, there is a selective bias because S-OIV prefers to mix with $\mathrm{ADV}, \mathrm{PIV}_{3}, \mathrm{PIV}_{4}$, and MPV (Fig. 2). Sputum culture was positive in Streptococcus pneumoniae (12.2\% and $26.7 \%$, respectively), Hemophilus influenzae (6.7\% and $0.0 \%$, respectively), Escherichia coli (6.7\% and $0.0 \%$, respectively), and Klebsiella pneumoniae ( $6.7 \%$ and $0.0 \%$, respectively) (Table 4 ). The S. pneumoniae co-infection in the IVA group was significantly less common than in the S-OIV group (Table 4; $\mathrm{p}<0.05$ ). All other concrete data is presented in Table 4.

In order to understand the difference of illness severity between IVA infection and S-OIV infection, we compared the indicators of average inpatient course, number of dyspnea patients, number of severe pneumonia cases, temperatures, and respiratory rates (Table 5). The results revealed that the average inpatient course was significantly longer in the IVA group compared to the S-OIV group (Table 5; $\mathrm{p}<0.05$ ). However, the other indicators were
Table 4. Co-infection of 90 IVA patients and 15 S-OIV patients

\begin{tabular}{|c|c|c|c|}
\hline Co-infection & $\operatorname{IVA}(\mathrm{n}=90)$ & $\begin{array}{c}\text { S-OIV } \\
(n=15)\end{array}$ & $p$-value \\
\hline \multicolumn{4}{|c|}{ Virus } \\
\hline RSV & 6.715 (16.7\%) & $1(6.7 \%)$ & 0.209 \\
\hline ADV & $6(6.7 \%)$ & $2(13.3 \%)$ & 0.491 \\
\hline PIV1 & $5(5.6 \%)$ & $0(0.0 \%)$ & 0.455 \\
\hline PIV2 & $1(1.1 \%)$ & $0(0.0 \%)$ & 0.320 \\
\hline PIV3 & $16(17.8 \%)$ & $5(33.3 \%)$ & 0.256 \\
\hline PIV4 & $1(1.1 \%)$ & $1(6.7 \%)$ & 0.424 \\
\hline hBoV & $7(7.8 \%)$ & $0(0.0 \%)$ & 0.328 \\
\hline hMPV & $2(2.2 \%)$ & $1(6.7 \%)$ & 0.526 \\
\hline hCoV & $4(4.4 \%)$ & $0(0.0 \%)$ & 0.535 \\
\hline \multicolumn{4}{|c|}{ Sputum culture } \\
\hline E. coli & $6(6.7 \%)$ & $0(0.0 \%)$ & 0.387 \\
\hline K.pneumoniae & $6(6.7 \%)$ & $0(0.0 \%)$ & 0.387 \\
\hline H. influenzae & $6(6.7 \%)$ & $0(0.0 \%)$ & 0.387 \\
\hline S. pneumoniae & $11(12.2 \%)$ & $4(26.7 \%)$ & $<0.05$ \\
\hline
\end{tabular}

IVA - seasonal influenza virus A; S-OIV - swine-origin influenza virus; PIV - parainfluenza viruses; RSV - respiratory syncytial virus; hMPV - human metapneumovirus; hCoV - human coronavirus; hBoV - human bocavirus; ADV - Aleutian disease virus; E. coli - Escherichia coli; K. pneumoniae - Klebsiella pneumoniae; H. influenzae-Hemophilus influenzae; S. pneumoniae - Streptococcus pneumoniae.

Table 5. Comparison of illness severity between IVA infection and S-OIV infection

\begin{tabular}{|c|c|c|c|}
\hline \multirow{2}{*}{ Variable } & \multicolumn{2}{|c|}{ Value } & \multirow{2}{*}{$p$-value } \\
\hline & IVA $(n=90)$ & S-OIV $(n=15)$ & \\
\hline $\begin{array}{l}\text { Average inpatient course } \\
\text { [days] }\end{array}$ & $7.73 \pm 9.16$ & $5.67 \pm 1.29$ & 0.042 \\
\hline Dyspnea case & $12(13.3 \%)$ & $1(6.7 \%)$ & 0.666 \\
\hline Severe pneumonia cases & $14(15.6 \%)$ & $1(6.7 \%)$ & 0.351 \\
\hline Temperature & $37.11 \pm 0.76$ & $37.44 \pm 0.92$ & 0.180 \\
\hline Respiratory rate & $42.51 \pm 11.54$ & $42.47 \pm 10.89$ & 0.857 \\
\hline
\end{tabular}

IVA - seasonal influenza virus A; S-OIV - swine-origin influenza virus.

not significantly different, which does not fully explain whether there is a significant difference in illness severity between IVA infection and S-OIV infection (Table 5).

The patients with severe pneumonia had more co-infection with RSV or ADV, and a higher prevalence of $K$. pneumoniae than the patients with mild pneumonia (Table 6). Severe pneumonia was also more common in patients with underlying conditions, such as congenital heart disease. Patients with severe pneumonia were basically similar in their incidence of the symptoms of cough, fever, sputum, dyspnea, etc. (Table 6). There is no statistically significant difference in WBC counts and CRP levels between severe and mild pneumonia. Meanwhile, in the IVA group, the CHD rate was significantly higher and the incidence of sputum was significantly lower in the severe pneumonia group compared to that of the non-severe pneumonia group (Table 6; $\mathrm{p}<0.05$ ). 
Table 6. Risk factors associated with severe pneumonia due to IVA and S-OIV

\begin{tabular}{|c|c|c|c|c|c|c|}
\hline \multirow[b]{2}{*}{ Variable } & \multicolumn{3}{|c|}{ S-OIV $(n=15)$} & \multicolumn{3}{|c|}{ IVA $(n=90)$} \\
\hline & $\begin{array}{l}\text { severe pneumonia } \\
(\mathrm{n}=1)\end{array}$ & $\begin{array}{c}\text { non-severe } \\
\text { pneumonia }(n=14)\end{array}$ & $\mathrm{p}$-value & $\begin{array}{l}\text { severe pneumonia } \\
\qquad(\mathrm{n}=14)\end{array}$ & $\begin{array}{c}\text { non-severe } \\
\text { pneumonia }(n=76)\end{array}$ & $p$-value \\
\hline Sex (male) & $1(100.0 \%)$ & $11(78.6 \%)$ & 0.800 & $8(57.1 \%)$ & $52(68.4 \%)$ & 0.298 \\
\hline Age (<2 years) & $1(100.0 \%)$ & $11(78.6 \%)$ & 0.800 & $13(92.9 \%)$ & $56(73.7 \%)$ & 0.107 \\
\hline \multicolumn{7}{|c|}{ Underlying medical conditions } \\
\hline Premature labor & $1(100.0 \%)$ & $2(14.3 \%)$ & 0.867 & $1(7.1 \%)$ & $7(9.2 \%)$ & 0.638 \\
\hline Previous respiratory infection $(\geq 3)$ & $1(100.0 \%)$ & $9(64.3 \%)$ & 0.667 & $7(50.0 \%)$ & $44(57.9 \%)$ & 0.770 \\
\hline Asthma & $0(0.0 \%)$ & $2(14.3 \%)$ & 0.867 & $12(85.7 \%)$ & $68(89.5 \%)$ & 0.484 \\
\hline CHD & $0(0.0 \%)$ & $0(0.0 \%)$ & 1.000 & $4(28.6 \%)$ & $3(3.9 \%)$ & $<0.05$ \\
\hline \multicolumn{7}{|c|}{ Symptoms } \\
\hline Cough & $1(100.0 \%)$ & $14(100.0 \%)$ & 1.000 & $13(92.9 \%)$ & $72(94.7 \%)$ & 0.580 \\
\hline Sputum & $0(0.0 \%)$ & $7(50.0 \%)$ & 0.533 & $13(92.9 \%)$ & $50(65.8 \%)$ & $<0.05$ \\
\hline Fever & $0(0.0 \%)$ & $0(0.0 \%)$ & 1.000 & $7(50.0 \%)$ & $47(61.8 \%)$ & 0.294 \\
\hline Wheezing & $1(100.0 \%)$ & $4(28.6 \%)$ & 0.333 & $4(28.6 \%)$ & 25 (32.9\%) & 0.508 \\
\hline Dyspnea & $0(0.0 \%)$ & $1(7.1 \%)$ & 0.933 & $4(28.6 \%)$ & $8(10.5 \%)$ & 0.088 \\
\hline Fatigue & $0(0.0 \%)$ & $0(0.0 \%)$ & 1.000 & $1(7.1 \%)$ & $5(6.6 \%)$ & 0.649 \\
\hline Sore throat & $0(0.0 \%)$ & $0(0.0 \%)$ & 1.000 & $0(0.0 \%)$ & $1(1.3 \%)$ & 0.844 \\
\hline Headache & $0(0.0 \%)$ & $0(0.0 \%)$ & 1.000 & $0(0.0 \%)$ & $2(2.6 \%)$ & 0.712 \\
\hline Chest pain & $0(0.0 \%)$ & $0(0.0 \%)$ & 1.000 & $0(0.0 \%)$ & $1(1.3 \%)$ & 0.844 \\
\hline Abdominal pain & $0(0.0 \%)$ & $0(0.0 \%)$ & 1.000 & $1(7.1 \%)$ & $1(1.3 \%)$ & 0.288 \\
\hline \multicolumn{7}{|c|}{ Co-infection with virus } \\
\hline RSV & $1(100.0 \%)$ & $1(7.1 \%)$ & 0.133 & $5(35.7 \%)$ & $10(13.2 \%)$ & 0.245 \\
\hline ADV & $1(100.0 \%)$ & $1(7.1 \%)$ & 0.133 & $2(14.3 \%)$ & $4(5.3 \%)$ & 0.233 \\
\hline PIV1 & $0(0.0 \%)$ & $0(0.0 \%)$ & 1.000 & $1(7.1 \%)$ & $4(5.3 \%)$ & 0.580 \\
\hline PIV2 & $0(0.0 \%)$ & $0(0.0 \%)$ & 1.000 & $0(0.0 \%)$ & $1(1.3 \%)$ & 0.844 \\
\hline PIV3 & $0(0.0 \%)$ & $5(35.7 \%)$ & 0.667 & $4(28.6 \%)$ & $12(15.8 \%)$ & 0.214 \\
\hline PIV4 & $0(0.0 \%)$ & $1(7.1 \%)$ & 0.933 & $0(0.0 \%)$ & $1(1.3 \%)$ & 0.844 \\
\hline HBoV & $0(0.0 \%)$ & $0(0.0 \%)$ & 1.000 & $2(14.3 \%)$ & $5(6.6 \%)$ & 0.298 \\
\hline MPV & $0(0.0 \%)$ & $1(7.1 \%)$ & 0.933 & $1(7.1 \%)$ & $1(1.3 \%)$ & 0.288 \\
\hline CoV & $0(0.0 \%)$ & $0(0.0 \%)$ & 1.000 & 1 (7.1\%) & $3(3.9 \%)$ & 0.498 \\
\hline
\end{tabular}

IVA - seasonal influenza virus A; S-OIV - swine-origin influenza virus; PIV - parainfluenza viruses; RSV - respiratory syncytial virus; hCoV - human coronavirus; hBoV - human bocavirus; ADV - Aleutian disease virus; CHD - coronary heart disease.

In multivariate analysis (Table 7), independent risk factors for the development of severe pneumonia were coinfection with $\mathrm{RSV}$ ( $\mathrm{p}=0.042$; $\mathrm{OR}=4.245 ; 95 \% \mathrm{CI}=1.052-$ 17.128), co-infection with ADV ( $\mathrm{p}=0.029$; OR $=7.336$; 95\% CI $=1.221-44.076)$, K. pneumoniae-positive sputum culture $(\mathrm{p}=0.022 ; \mathrm{OR}=7.763 ; 95 \% \mathrm{CI}=1.342-44.896)$, and basic condition of congenital heart diseases $(\mathrm{p}=0.009$; $\mathrm{OR}=9.577 ; 95 \% \mathrm{CI}=1.777-51.610$ ).

\section{Discussion}

This study compared the characteristics of pediatric patients with seasonal influenza to those with $\mathrm{H} 1 \mathrm{~N} 1$ infection and analyzed the risk factors for development of severe pneumonia.
Our findings are consistent with other reports in that the clinical features of S-OIV infection are generally similar to those of seasonal influenza infection..$^{14,15}$ The most common symptoms were cough, sputum and fever, while the symptoms of fatigue, sore throat, headache, abdominal pain, and chest pain were rare in pediatric patients. Young children cannot formulate complaints, which probably helps explain the less common symptoms.

Studies have previously indicated that many hospitalized patients during the peak periods of seasonal influenza were usually younger than 2 years or older than 65 years. ${ }^{16,17}$ In our groups, patients under the age of 2 years represented 79 (76.6\%) and 12 (79.9\%) cases, suggesting that infants and children under 2 years are the most susceptible group for seasonal influenza and S-OIV in Chongqing. ${ }^{18}$ The reason may be that infants and children less than 2 years old lack 
Table 7. Multivariable analysis of risk factors associated with severe pneumonia

\begin{tabular}{|c|c|c|c|c|c|}
\hline \multirow{2}{*}{ Variable } & \multicolumn{2}{|c|}{ IVA $(n=90)$} & \multicolumn{3}{|c|}{ Model } \\
\hline & severe pneumonia $(n=14)$ & non-severe pneumonia $(\mathrm{n}=76)$ & OR & $95 \% \mathrm{Cl}$ & $p$-value \\
\hline Sex (male) & $8(57.1 \%)$ & $52(68.4 \%)$ & 0.595 & $0.192-1.847$ & 0.298 \\
\hline Age (<2 years) & $13(92.9 \%)$ & $56(73.7 \%)$ & 5.141 & $1.742-48.430$ & 0.107 \\
\hline $\mathrm{CHD}$ & $4(28.6 \%)$ & $3(3.9 \%)$ & 9.577 & $1.777-51.610$ & $<0.05$ \\
\hline \multicolumn{6}{|c|}{ Symptoms } \\
\hline Cough & $13(92.9 \%)$ & $72(94.7 \%)$ & 0.138 & $0.007-2.755$ & 0.580 \\
\hline Sputum & $13(92.9 \%)$ & $50(65.8 \%)$ & 6.330 & $0.740-54.133$ & $<0.05$ \\
\hline Fever & $7(50.0 \%)$ & $47(61.8 \%)$ & 1.321 & $0.345-5.066$ & 0.294 \\
\hline \multicolumn{6}{|c|}{ Co-infection with virus } \\
\hline RSV & $5(35.7 \%)$ & $10(13.2 \%)$ & 2.360 & $0.345-16.137$ & 0.245 \\
\hline ADV & $2(14.3 \%)$ & $4(5.3 \%)$ & 1.736 & $0.136-22.167$ & 0.233 \\
\hline PIV3 & $4(28.6 \%)$ & $12(15.8 \%)$ & 2.652 & $0.446-15.771$ & 0.214 \\
\hline \multicolumn{6}{|c|}{ Sputum culture } \\
\hline E. coli & $2(14.3 \%)$ & $4(5.3 \%)$ & 1.025 & $0.078-13.405$ & 0.985 \\
\hline K. pneumoniae & $3(21.4 \%)$ & $3(3.9 \%)$ & 3.242 & $0.336-31.275$ & $<0.05$ \\
\hline H. influenzae & $1(7.1 \%)$ & $5(6.6 \%)$ & 0.334 & $0.006-19.456$ & 0.597 \\
\hline S. pneumoniae & $1(7.1 \%)$ & 10 (13.2\%) & 0.299 & $0.020-4.523$ & 0.383 \\
\hline
\end{tabular}

OR - odds ratio; 95\% CI - 95\% confidence interval; CHD - coronary heart disease; PIV - parainfluenza viruses; RSV - respiratory syncytial virus; ADV - Aleutian disease virus; E. coli - Escherichia coli; K. pneumoniae-Klebsiella pneumoniae; H. influenzae-Hemophilus influenzae; S. pneumoniae - Streptococcus pneumoniae.

elastic tissue and mucus gland secretion and have poor cilia movement, which leads to a lower non-specific immune response. ${ }^{19}$

In the comparison of clinical characteristics between IVA and S-OIV patients, we find that the former group has a higher average inpatient course and more cases of dyspnea and severe pneumonia. Although these are not statistically significant, in view of the mere 15 S-OIVpositive cases, it cannot be completely excluded that there is a difference in illness severity between them. According to our data, there is a strong possibility that the pediatric patients with IVA infection have more severe cases than patients with S-OIV. Brundage and Shanks have reported that the replacement of amino acids in the PB2, NS1 and PB1-F2 proteins of the influenza virus has a direct impact on virus virulence. ${ }^{20} \mathrm{~S}$-OIV possesses fewer pathogenic amino acid sites in the PB2, NS1 and PB1-F2 proteins than IVA, which may be one explanation.

The study shows that the conditions of congenital heart disease, K. pneumoniae-positive sputum culture, and coinfection with RSV or ADV are risk factors for developing severe pneumonia. Other reports reveal that mixed IVA pneumonia is 3 times more prevalent than simple influenza pneumonia, ${ }^{21,22}$ regardless of the seasonal flu or S-OIV in 2009. The most common bacteria in mixed pneumonia are S. pneumoniae, H. influenzae and Staphylococcus aureus - especially S. pneumoniae, ${ }^{23}$ which is in accordance with our study.

Influenza pneumonia co-infection with S. pneumoniae easily develops into severe pneumonia and raises the mortality rate. ${ }^{23,24}$ Two mechanisms for this phenomenon have been reported. Firstly, animal experiments show that the $\mathrm{H} 1 \mathrm{~N} 1$ virus mixed with $S$. pneumoniae can induce a synergistic role in enhancing the expression of plateletactivating factor receptor; in consequence, S. pneumoniae is easier to adhere to and increases damage to the lungs. ${ }^{23}$ Secondly, a mixed infection of the two can upregulate interleukin 1 (IL-1) expression, which reduces the macrophage clearance of $S$. pneumoniae. ${ }^{24}$ However, our results suggest that the condition of $S$. pneumoniae-positive sputum culture is not a statistically significant factor, while a K. pneumoniae-positive sputum culture $(\mathrm{p}=0.023$; $\mathrm{OR}=7.250 ; 95 \% \mathrm{CI}=1.311-40.098$ ) is one of the risk factors for the development of severe pneumonia in children hospitalized with respiratory tract IVA infections. This phenomenon has not yet been clearly reported in the literature: only 1 case report has been published in Taiwan, which found that IVA mixed with $K$. pneumoniae in nasopharyngeal carcinoma patients appear to pneumonia and progressive dyspnea. ${ }^{25,26}$ In conclusion, the synergistic effect and its mechanism of IVA co-infection with K. pneumoniae require further study.

We recognize several limitations in our study. Notably, imaging data was not included, some laboratory values were missing and some symptoms may have been underreported through poor clinical recognition. Furthermore, the S-OIV-positive cases were too few (only 15 cases) - the relationship between S-OIV and severe pneumonia requires a larger sample size for further study.

The IVA spreads throughout the year, and regional epidemics or worldwide pandemics occur frequently. 
As it is one of the most common pathogens in children with respiratory tract infection, determining the prevalence, clinical characteristics and risk factors of severe pneumonia in children with ARIs in Chongqing can be important to its clinical diagnosis, treatment and vaccination.

Although the present study resulted in some interesting findings, there were also limitations. As it is wellknown, many risk factors - such as current body weight, birth weight, anemia, and familial diseases - may lead to severe pneumonia in hospitalized pediatric patients. However, these risk factors were not discussed in this study. Therefore, in the following study, we would also investigate the effects of the above risk factors on severe pneumonia.

\section{Conclusions}

The study indicated that the detection rates of S-OIV infection and seasonal IVA were $1.4 \%$ and $8.4 \%$, respectively, in children hospitalized with acute airway respiratory infection in Chongqing. Children younger than 2 years appeared to be susceptible to both viruses. A diagnosis of non-severe respiratory tract infection was mainly presented in patients hospitalized with S-OIV and IVA infection in the respiratory medicine division of our hospital. Underlying heart conditions, wheezing and co-infection with adenovirus all increase the risk of developing severe pneumonia in patients with seasonal IVA infection.

\section{References}

1. Fouchier RA, Munster V, Wallesten A, et al. Characterization of a novel influenza A virus hemagglutinin subtype (H16) obtained from blackheaded gulls. J Virol. 2005;79(5):2814-2822.

2. Piyarat S, Kano KS, Pranee S, et al. Clinical and epidemiological characteristics of respiratory syncytial virus and influenza virus associated hospitalization in urban Thai infants. J Med Assoc Thai. 2011; 94(Suppl 3):S164-S171.

3. Taubenberger JK, Huhin JV, Morens DM. Discovery and characterization of the 1918 pandemic influenza virus in historical context. Antivir Ther. 2007;12(4 Pt B):581-591.

4. Peiris JS, Poon LL, Guan Y. Emergence of a novel swine-origin influenza A (H1N1) virus in humans. J Clin Virol. 2009;45(3):169-173.

5. Muhammad Ismail HI, Tan KK, Lee YL, et al. Characteristics of children hospitalized for pandemic (H1N1) 2009 in Malaysia. Emerg Infect Dis. 2011;17(4):708-710.

6. Falagas ME, Kiriaze IJ. Reaction to the threat of influenza pandemic: The mass media and the public. Crit Care. 2006;10(1):408.
7. Piekarska K, Zacharczuk K, Wolkowicz T, et al. Distribution of $16 \mathrm{~S}$ rRNA methylases among different species of aminoglycoside-resistant Enterobacteriaceae in a tertiary care hospital Poland. Adv Clin Exp Med. 2017;25(3):539-544.

8. Halasa NB. Update on the 2009 pandemic influenza A H1N1 in children. Curr Opin Pediatr. 2010;22(1):83-87.

9. Wang C, Liu Y, Wang Y, et al. Adenovirus-mediated siRNA targeting CXCR2 attenuates titanium particle-induced osteolysis by suppressing osteoclast formation. Med Sci Monit. 2016;22(1):727-735.

10. Xu W, McDonough MC, Erdman DD. Species-specific identification of human adenoviruses by a multiplex PCR assay. J Clin Microbiol. 2000;38(11):4114-4120.

11. Allander T, Jartti T, Gupta S, et al. Human bocavirus and acute wheezing in children. Clin Infect Dis. 2007;44(7):904-910.

12. Call SA, Vollenweider MA, Hornung CA, Simel DL, McKinney WP. Does this patient have influenza? JAMA. 2005;293(8):987-997.

13. Cox NJ, Subbarao K. Influenza. Lancet. 1999;354(9186):1277-1282.

14. Fiore AE, Shay DK, Broder K, et al; Centers for Disease Control and Prevention. Prevention and control of influenza: Recommendations of the Advisory Committee on Immunization Practices (ACIP). MMWR Recomm Rep. 2009;58(RR-8):1-52.

15. Thompson WW, Shay DK, Weintraub E, et al. Influenza associated hospitalizations in the United States. JAMA. 2004;292(11):1333-1340.

16. Monies M, Vicente D, Perez-Yarza E, Cilla G, Pérez-Trallero E. Influenza-related hospitalizations among children aged less than 5 years old in the Basque country, Spain: A 3-year study (July 2001-June 2004). Vaccine. 2005;23(34):4302-4306.

17. Neuzil K, Zhu Y, Griffin M, et al. Burden of inter-pandemic influenza in children younger than 5 years: A 25-year prospective study. Infect Dis. 2002;185(1):147-152.

18. Neumann G, Noda T, Kawaoka Y. Emergence and pandemic potential of swine-origin H1N1 influenza virus. Nature. 2009;459(7249): 931-939.

19. Morens DM, Taubenberger JK, Fauci AS. Predominant role of bacterial pneumonia as a cause of death in pandemic influenza: Implications for pandemic influenza preparedness. J Infect Dis. 2008;198(7): 962-970.

20. Brundage JF, Shanks GD. Deaths from bacterial pneumonia during the 1918-1919 influenza pandemic. Emerg Infect Dis. 2008;14(8): 1193-1199.

21. Wunderink RG. Influenza and bacterial pneumonia, constant companions. Crit Care. 2010;14(3):150.

22. Chertow DS, Memoli MJ. Bacterial coinfection in influenza: A grand rounds review. JAMA. 2013;309(3):275-282.

23. McCullers JA, Jerold ER. Lethal synergism between influenza virus and Streptococcus pneumoniae: Characterization of a mouse model and the role of platelet-activating factor receptor. J Infect Dis. 2002;186(3): 341-350.

24. Shigeki N, Kimberly MD, Jeffrey NW. Synergistic stimulation of type I interferons during influenza virus coinfection promotes Streptococcus pneumoniae colonization in mice. J Clin Microbiol. 2011;121(9): 3657-3665.

25. Lai CC, Lee PL, Tan CK, et al. Pneumonia due to pandemic (H1N1) 2009 influenza virus and Klebsiella pneumoniae capsular serotype K16 in a patient with nasopharyngeal cancer. J Microbiol Immunol Infect. 2011;45(5):382-384.

26. Radzikowska E, Rozy A, Jagus P, et al. Clarithromycin decreases IL-6 concentration in serum and BAL fluid in patients with cryptogenic organizing pneumonia. Adv Clin Exp Med. 2016;25(5):871-878. 